Tamara Stanković, Ph.D. student, UniversitySingidunum

Slobodan Čerović, Professor, UniversitySingidunum

DOI 10.5937/turpos0v-31295

UDK 316.77:004.773

659.186:640.412

005.336.3:[659.131.7:004.738.5

\title{
THE IMPACT OF INTERNET DISTRIBUTION SYSTEMS ON THE PROMOTION, SALES, AND QUALITY OF HOTEL ACCOMMODATION (WITH 4 AND 5 STARS IN THE CITY OF NIŠ)
}

The abstract: This work is a theoretical and empiricaloverview of the influence of IDS and social networks on the promotion, sales, and quality of hotel accommodation. The work outlines a theoretical-academic presentation and includes a case study, which was carried out through research in 4-star and 5-star hotels. The research identifies the usage and influence of IDS on promotion, sales, and quality of hotel accommodation, the key advantages of cooperation and areas where it is lacking, as well as the usage and importance of social networks in promotion and sales. The terms "IDS" and "social networks in hotel businesses," their definition and importance are presented in the theoretical part of this work. The focal point of this work is to prove the importance of applying IDS and social networks in promotion, sales, and quality of services, in addition to showingthe advantages of cooperation and areas where it is lacking. Furthermore, this work emphasizes the importance of staying up to date and in agreement with the latest innovations and their usage in the hotel industry, as well as the significance of adjusting the offer and services to the market demand.

Keywords: Internet distribution systems, social networks, promotion, sales, quality.

\section{Introduction}

Globalization and widespread use of the Internet on the global scale have brought about a new type of tourist, the so-called "digital tourists." Digitalization and the Internet have led to a more contemporaneous approach to doing business, especially in tourism and hospitality. Through the frequent usage and application of modern informational and technological resources in a business environment, mobile technologies, Internet browsers and impactful social networks have gradually become the principal means of communication and performance of various business activities across all domains of tourism and hospitality. The general availability of information has led to a global, worldwide market. Nowadays, it is virtually impossible to approach the topic of business in tourism and hospitality without adjusting to the new technologies which arise in all its domains. The advantages of using modern technology in business are reflected in the increased productivity, higher quality of provided services, reduced costs of business, long-term profitability, as well as in the increased satisfaction of hotel guests. Namely, every hotel business needs to identify the potential advantages of their business and adapt their offer to the market demands, while aspiringto make their services more attractive than those of their competitors. The main point of Internet distribution systems (IDS) is selling hotel accommodation. Thanks to the Internet, especially the development of Internet distribution systems (IDS) and the evolution of social networks, promotion, and sales of hotel accommodation became easier and we can see a big difference. Today, a potential tourist usesthe Internet if he wants to do research onthe desired hotel whereas in the past they did it exclusively through brochures, magazines, posters, etc. 


\section{Use of modern information technology in hospitality}

Globalization, development of the Internet, and modern technologies have led to considerable advancement of business in tourism and hospitality. Research done by the experts at the ITU(International Telecommunication Union), an internationalspecialized agency of the UN for information and communication technology, states that there are 3.4 billion Internet users at the present moment, which makes up almost half of the world population. Having this information in mind, it is evident that connection and communication in the world have never been so simple. (Kovačević et al, 2016) With the appearance and development of modern technologies, including the Internet, a change in the marketing concept of promoting and selling hotel services has occurred.

It has been noted that "Internet marketing consists of online advertising which in turnis made up from banners, blogs, mass email campaigns, etc., in addition to e-sales, development of public relations via the Internet and social networks." (Šarac,2015,2) Along the same lines, "digital marketing encompasses the promotion of services and goods via digital channels of communication, so that specific message is delivered to the primary group of consumers or wide audience."(Ryan et Jones,2009,24)

Digital VS Internet marketing: The difference between digital and Internet marketing is that Internet marketing represents just one of the categories of digital marketing. That category, or rather subcategory, is the most important because most digital activities are included in it. The following online channels are part of Internet marketing: banners, web pages, content marketing, SEO, email, mobile marketing, marketing on social networks, and marketing on browsers(Sorkup et al, 2009, 124) (Popesku, 2013, 195). In the opinion of Baker and Hart(Baker at Hart, 2008, 694), digital marketing is, actually, direct marketing which is implemented through new media. Through the development of digital marketing, we have also developed a set of tools that are used in it, and communication has transformed from impersonal into different forms of personal communication. Internet marketing requires constantly following the latest trends and improvementsin accordance with those innovations. Innovations have become crucial for market competitiveness, and different competitors aspire to introduce the innovations first to the market and to be novel in different aspects. Advantages of digital marketing lie in itsconvenience, the lack of inconvenient situations, and the fact that information is readily available at everymoment. (Ryan et al, 2008, 123) According to Živković(2011, p. 13),four key elements shape modern businesses and have influence over it:

1. Expansion of Internet;

2. Digitalization and interconnectedness;

3. Adjustment to newly-created changes and customer expectations;

4. Modern ways of Intermediation

Companies that use the Internet in their businesses are characterized by the following: improved quality of service, low prices, lower costs, wider and better assortment of services, customization of services and products, new ways for creating a marketing mix.(Jobber et al, 2006,157 ) Internet is a powerful medium of the whole marketing mix in tourism and hospitality.(Buhalis at Law, 2008)According to Jobber at Ellies-Chadwich (2006, p.156), Internet marketing entails the distribution of products and promotional benefits of customers, as well as the information given to customers or companies through the application of modern internet technologies. Internet marketing can be defined, in other words, asthe fulfillment of the marketing goals of a company through the usage of modern technologies, primarily with the usage of the Internet.(Robert at Zahay, 2012) Usage of the Internet in the business of companies is characterized by: the development of quality service, customization of products, making 
innovative ways for making a marketing mix, a variety of products, lower prices, and costs.(Jobber at Ellis-Chadwick, 2012) (ElGohary, 2012) (Jobber at Fahy, 2006, 157)

The key to the successful management of tourism and hospitality companies lies in the usage of modern information-communication technologies in business management and channels of distribution, and this represents the key feature of business competitiveness. (Bahaliset Molinaroli, 2003) The development of computer reservations systems during the 70 s, the introduction and development of global distribution systems during the $80 \mathrm{~s}$, further development and improvement of the Internet during the $90 \mathrm{~s}$, as well as all further innovations, led to important differences in business management of hotels - this was primarily the placement of new technologies that were not accepted well from the hoteliers, although they hadan important influence on the ease of doing business.(Law et Jogaratnam, 2005)

The use of modern information technologies and electronic business contributed to the reduction in differences between direct and indirect sales. For example, online sale is available to all potential customers, as well as to travel agencies. Hotel businesses use their online channels, which are available to all people, too. Growing computerization clearly shows the advantages which modern technology providesin order to have a successful business. Advantages that we can have with direct contact with customers are:(Buhaliset Law, 2008)

results

- Perception of accomplished work

$$
\text { and measuringsale efficiency; }
$$

- Advancements in marketing;

- Customer databases, which provide a possibility of getting to know the customers completely;

- The effectof potential customers'inquiry and determination of costs.

Holloway $(2004,198)$ emphasizes that electronic intermediaries which played a big role in the acceptance of modern information technologies by hoteliers and, in turn, connected buyers and industries globally provideat least several benefits:

1. Lower costs in a business;

2. Contact with customers;

3. Mutual connection with customers;

4. Maximum speed in communication.

Online sales, reservations, and information via Internet have increased significantly, today they are at $90 \%$.(Kotler et al, 2010, 688) There are 2 types of sales through the Internet, and the first type is disintermediation, which provides direct contact between potential customers and businesses, which means avoiding provisions and mediators. The second type of Internet sales is reintermediation, which introduces new mediators which give the possibility of buying viathe Internet, for examplethrough booking. com.(Kauffman et Chircu, 2000)(Green at Lomanno, 2012)

Tourism (trips) and tourist services are in the $5^{\text {th }}$ place among the most wanted products on the Internet.(Eyefotravel, 2012)Trips and tourism services have specific characteristics which make them suitable for the Internetmarket and sales - they are intangible,heterogeneous, they haverelatively high prices and high participation.(Burger et al, 1997)

Distribution mediators in an industry of tourism enable these benefits: (Holloway, 2004)

- Internal stable connection with tourists;

- Effective contact with buyers;

- High-speed communication;

- Minimal costs in business management.

The European Commission has classified numerous companies into few logical groups according totheir business characteristics (Knežević et al, 2014) (European Commission, 2013):

- Internet Distribution Systems (IDS), like booking.com

- Global distribution systems (GBS), like Amadeus 
- Central reservation systems (CRS), like Hotelbeds

- Brands, like Leading Hotels

- Info companies, like Trip advisor

- Inno-mediators, like Let's bonus and Groupon.

The need for modern technologies in hotels came to be because of the massive number of reservations, as well as because of other needs, which were made easier and more feasible through modern technologies. That is how the hotel system of reservationswas created. This system is made of two main integrated modules(Njeguš, 2010, 150):

1. System for management of hotel property;

2. Computer reservation system.

\subsection{Influence and use of IDS in the hotel business}

The main form of reservation of hotel vacancies and capacities all over the world is through online reservation systems. In the hotel sector, there are a lot of research studies that deal with the development of the Internet, like mediation(Brewer et al, 2006), prices of hotel accommodation(Tso et Law, 2005), online distribution(Morosan et Jeong, 2008), and websites(Law et Cheung,2006). With the arrival of new technological solutions, a special type of travel agency was designed (the agency is an Internet distribution system or online agency). The first online agency, which was founded in 1996 in America, is Travelocity.com, and its creator was GDS-Sabre. Then, Microsoft offered Expedia.com, and subsequently, other agencies followed, modeled on booking.com, which is a leader in the field today(Čomićet Kalmić,2011).

Online agencies possess a huge database on available accommodation capacities, prices of hotel services, all information needed for reservation and payment, as well as photos of the hotels, while lately videos of hotels have been introduced, as well. Online sales have recorded, one year after another, huge growth which led to the inception of online companies or metasearchengines, like Side59.com.(Spasić at Pavlović, 2013) (O'Connor at Frew, 2002) (Toh et al, 2011) (Biederman, 2008, 366)

IDS offers to their customers an independently planned and complete trip (hotel, flight, transportation, and additional activities on the premises). They also present a chance for the tourists to find information about the destination before the trip, or about the activities and amenities on the premises, to find out more about the desired area, to plan and reserve additional services on the trip, etc. IDS also provides a possibility for customers to change their travel package details(Del Chiappa, 2013).

Global business orientation, the entrance of new market competitors, and their orientation towards new markets are some of the characteristics of the changes that happened in the competitor relationships due to electronic and technological causes. (Spasić et Pavlović, 2013,4)

The appropriatemaintenance of the online reputation of a hotel by its managers is very important for the tourist destinations thatoffer a more diverse selection and visited more than the competitor destinations(Cantallopset Salvi, 2014). The most frequented destinations offer a great number of hotels from the same category, which have similar prices of accommodation and vacancies, which makes it more difficult for potential tourists to choose from. In situations like this, the main decision depends on online comments and ratings from the guests that have already stayed in the hotel. Guests, in situations like this, mostly choose certain hotels based on positive and negative comments, which proves to be the easiest method when selecting a hotel(Xie et al, 2014).

To determine the quality of provided services in the hotel industry, it is necessary to measure the satisfaction of customers with provided services. 
By determining the quality of provided services, managers of hotels measure quality-of-service processes in an objective way (Barjaktarović, 2014, 226). Service quality, with the goal of satisfying the consumers' needs and wishes, enables:

- WOM- word of mouth, verbal promotion with the goal of attaining customer loyalty;

- The employee satisfaction, motivation towards the goal of realizing better work results;

- The higher value of service, competitive price advantage, reduction of hotel costs.

"Word of mouth" - is a type of promotion straight from one person to another, which has proven to be extremely important to managers of hotels as a means of promotion of hotel service quality, transmitted from the consumer (someone who stayed in a hotel, experienced something positive or negative) to other potential consumers. That is an organic advertisement, which cannot be paid for, and it is very important in the world of hoteliers, because of the intangibility of hotel services. A lot of researches proved that the comments of guests are very important, too, because they directly affect the popularity of hotels(Hennig-Thuranet al, 2004; Litvinet al, 2008).

According to Ye et al (2009), the online rating of hotels and achieved business results of the hotels are directly connected. Also, it is established that online comments of guests and their ratings based on hotel stays, as well as ratings based on the quality of given services, directly influence sales of hotel services(Browning et al, 2013). O'Connor(2010) asserts that online comments of guests are very important and that every modern hotel manager should closely monitor them, accordingly improving their business and learning from mistakes. It is necessary to develop online communication channels with customers in order to improve the digital reputation of the hotel. Ye(2011), based on his conducted researches, established that an increase in positive comments of $10 \%$ brings to an increase in salesof $4,4 \%$, while in the opposite case with $10 \%$ of negative comments, the reduction of sales of $2,8 \%$ is brought about, which testifies to a big difference and leads to the conclusion that positive comments have a tremendous influence on customers. Papthanassiset Knolle(2011), conducted research thatresulted in a claim opposite to the previous one. They claim that negative comments have a bigger influence than positive comments as the customers feel they are more relevant and prioritize them compared to the positive ones. Also, Clemons et Gao(2008) agree with these claims, statingthat negative comments are the preferred ones and that consumers read negative commentsfirst, which are, according to their research, clearer, more precise, and more convincing. IDS, thanks to globalization and modernization of more recent times, has become a very important assessment instrument for the quality ofhotel service. (Hu et al, 2012)(Litvinet Hoffman, 2012) Through numerous portals available on the Internet, like booking.com, Expedia, Travelocity, etc., guests can input comments and ratings, based on the quality of provided hotel services and other contents. The final rating, a cumulative assessment, is made by the interpersonal agreement of numerousconsumers. It is not possible to delete, filter out or create tailored selections of comments(Minazzi, 2015, 109) (Mukherjee et al, 2012). 


\subsection{Advantages and disadvantages of distribution through the Internet}

Key advantages of IDS:

- Reduction of administration costs;

Visibility on the Internet 24/7;

- Offers can be translated into more than 20 languages;

- Connection with sites thathold useful information;

- Increased ROI and income;

- Receiving and forwarding payment immediately;

- Changing prices in accordance with the demand on the market;

- More efficient management with last minute offers;

- Staff reduction;

- Price strategy for each unit;

- Preserving comments and important marketing strategies.

www.hospitalitvoerformancegroup.com/index. oho/distribution/42-ids/58-ids-internetdistribution-svstem.html

Hotel websites have a lot of advantages, as well as disadvantages. The key advantage is the total control over the hotel web content on the web page, while the control of the content on online portals is not possible. Also, making a web page for hotels is not too expensive, while access to online portals is much more expensive(Đorđević, 2012) Electronic mediators have their advantages (Anderson, 2011):

- IDS fills hotel capacities much faster and more efficiently;

- Making higher income;

- IDS promotes hotels, but also destinations where the hotel is located;

- Billboard effect - increases traffic through the website of hotels;

- It gives the opportunity to small hotels to approach the global market.
By comparing classical mediators and electronic mediators, electronic mediators have shown a lot of advantages (Spasićet Pavlović, 2013):

- Lower costs

- More attractive prices

- Doing businesses more efficiently.

Key disadvantages of distribution through the Internet (Živković, 2011):

- Requires trust (on purchase);

- Possible abuse of payment cards;

- Insecurity of transactions;

- Endangering privacy;

- Connection speed;

- A certain number of people do not use the Internet.

\section{Digital media and social networks in the hospitality}

The Internethas globally become the main source of information, where people from different areas and industries can access a variety of information. In most cases, potential users are looking for information on the web, but a great number of users are looking for information on social networks, too. An online community represents a group of people who communicate with other people exclusively through social networks. Media, through globalization, digitization, and networking, have become one form of doing business. Media can act locally or nationally, but the production and income are global. Social media act globally, and they are customized to all the laws and acts of a country. A very popular way of marketing is viral marketing. Viral content is word of mouth using online channels. Social media representa form of electronic communication, via which users createan online community. The two most important characteristics of social media are (Lekhanya, 2014): 
1. Connecting people;

2. Creating interpersonal relations.

Social media represent a means of transmittingor sharing information with other people using web technology. Social media can be divided into (Lincoln, 2009):

1. Social networks;

2. Blogs;

3. Microblogs;

4. Multimedia exchange services;

5. Widgets.

By usingsocial media, a company (hotel) is given a chance to establish communication with consumers and to give them stimulation. Creating blogs, making profiles on social networks, connecting to forums related to trips and travel -these are all various activities and ways of communication through social media. Hotels have various benefits from communication through social media (Minazzi, 2015, 52):

- improvement of knowledge,

- the possibility of increasing the sales rate,

- commission reduction,

- increase in positive promotion by WOM,

- increase and stimulation of vacancy sales,

- increasein trust and obtaining loyal customers. .

Social networks representa system where it is possible to make new acquaintances, communicate, share photos, collect information and other content. The first form of this type of network was made in the $90 \mathrm{~s}$ - the so-called chatting. At the turn of the century, social networks improved and grew into what we know today. Social networks, according to Lekhanyay(2014), are structures that connect people from different areas, different interests. Hospitality was among the first to introduce innovations and information technologies. Web sites, like hotel profiles, too, on social media, need to be creative, updated, to have useful information, to contain a virtual display of the destination, to contain comments, recommendations, and advice, calendar of events, contact, and a map (Stankovićet al, 2013, 82).

Hoteliers are obligated to check email regularly, and their social profiles on Facebook or Instagram, for example. In addition, they need to pay special attention to the comments, reviews, as well as tourist questions on their website. To be successful on social networks, besidesfrequent updates and creative content, it is necessary to reply quickly to tourist messages, as well as to be always online. A lot of hotels do not use social networks properly. Certainly, it is better not to use social networks for purposes of promotion, than to use them in the wrongway(Xiang et al, 2014, 55). Travelers use the Internet as the main starting point for finding tourist destinations and reserving a hotel room.(Phelan et al, 2013, 134)

Social networks affect consumers in the processes of purchasing a hotel product or service, or trips, at all stages of the purchase.(Schindler et al, 2005, 148) Google Think Insight(Google, 2013) conducted research ona group of tourists who are going on trips for business or pleasure. The research showed that in the first stage, the stage before thetrip, online activities significantly increase: watching materials, destination research, reading reviews of guests on social networks or portals, like booking.com, watching video materials, sharing ideas and experiences, doing detailed research before going on a trip.(Xiang et al, 2014) In the second stage, the stage during the trip, a tourist is still researching for the information on the destination. For example, a tourist puts some ratings online, on the TripAdvisor site, where he describes in detail his current experience or shares a story on Instagram or Facebook account, or adds pictures with comments.

During the trip, in case of dissatisfaction of tourists, the hotel can react and improve the experience. In the third stage, the stage after the 
trip, a tourist evaluates the quality of provided services. In this case, hoteliers cannot react anymore and try to change that. Also, they cannot remove negative comments or ratings. As in the case of complaints made by the tourists, a hotel undertakes improvement measures, because the complaint is essential for the hotel and its customer care (Kaplan et Haenlein, 2011).

A tourist evaluates the quality of provided services, comments experience, shares experience from the trip on sites like TripAdvisor, booking.com, etc. Social networks, like Facebook, Instagram, Twitter, and others, can stimulate the consciousness of tourists to new trips. High numbers of tourists decide on certain trips, looking at or researching about certain destinations (Minazzi, 2015).

Based on data from 2017, the top 5 most visited social networks are as listed:

1. Facebook 1.1 bil.

2. YouTube 1 bil.

3. Twitter $310 \mathrm{mil}$.

4. Linkedin $250 \mathrm{mil}$.

5. Pinterest $225 \mathrm{mil}$.

During the trip, in case of dissatisfaction of tourists, the hotel can react and improve the experience. In the third stage, the stage after the trip, a tourist evaluates the quality of provided services. In this case, hoteliers cannot react anymore and try to change that. Also, they cannot remove negative comments or ratings. As in the case of complaints made by the tourists, a hotel undertakes improvement measures, because the complaint is essential for the hotel and its customer care (Kaplan et Haenlein, 2011).

A tourist evaluates the quality of provided services, comments experience, shares experience from the trip on sites like booking.com, etc. Social networks, like Facebook, Instagram, Twitter, and others, can stimulate the consciousness of tourists to new trips. High numbers of tourists decide on certain trips, looking at or researching about certain destinations (Minazzi, 2015).

Based on data from 2017, the top 5 most visited social networks are as listed:

\section{Facebook 1.1 bil.}

2. YouTube 1 bil.

3. Twitter $310 \mathrm{mil}$.

4. Linkedin 250 mil.

5. Pinterest 225 mil.

booking.com, etc. Social networks, like Facebook, Instagram, Twitter, and others, can stimulate the consciousness of tourists to new trips. High numbers of tourists decide on certain trips, looking at or researching about certain destinations (Minazzi, 2015).

Based on data from 2017, the top 5 most visited social networks are as listed:
1. Facebook 1.1 bil.
2. YouTube 1 bil.
3. Twitter $310 \mathrm{mil}$.
4. Linkedin $250 \mathrm{mil}$.
5. Pinterest $225 \mathrm{mil}$.

The tendency of potential tourists to use social networks in different stages of trips differs culturally and with age(Wilson et al, 2012). In Serbia, according to global Internet statistics, there are $66,6 \%$ Internet users, thereof $47,6 \%$ are Facebook users. Users of social networks research the destination before the trip, to be informed about the hotel, and in $33 \%$ of cases change the hotel after informing themselves, and in $10 \%$ of cases, they change the mediator.In $10 \%$ they change the destination, and in 5-7\% they change the country of travel. Reviews on hotelsare posted by $46 \%$ of tourists, and $76 \%$ of tourists share their pictures on social networks during and after the trip, and in that way, 
promotion and sales of services are performed. (Nielsen, 2012)

Reasons for opening Facebook company profile: free WOM, visibility, connection, insights.

Paid advertising tools on Facebook company profile are, among others(Minazzi, 2015):

$>$ Offers - specified posts that provide an opportunity for all hotels to promote the service to an appropriate group of people (potential tourists). For example, a hotel can publish its promotional price of accommodation vacancies in the preseason (during May) and provide the possibility of taking the offer via coupons.

$>$ Sponsored stories-advertising messages which are shown to followers on the news feed. Facebook chooses followers based on recent interests. For example, followers of the hotel's fan page on Facebook or Instagram will get a news feed of the hotel and all new notifications about it,too.

$>$ Advertising campaign -Ad

campaignsconsist of 3 levels:

1.Campaign - has a specific advertising goal, hotels can have few goals:

- Clicks to Website;

- Page Post Engagement;

- Page Like;

- App Installs

- Event Responses.

2. Adset-a specific way of marketing in that it defines one or more target groups, based on demographic data, location, Interests, etc. Based on the collected data, we get the number of people to which advertisements should arrive, who will likely be interested. In the end, the results of the activity are obtained.

3. Ads-messages of promotional nature. The company directs the messages to a certain group of people. The information on the target group is collected through personal data and type of offers. Messages of this type consist of a title, video, or pictures, and they are shown on the home page of Facebook or Instagram. The development of social networks has an influence on hotel management. The instability and insecurity in hotel management occur as a result of using social networks. (Lagrosen at Josefsson, 2011)Because of everything mentioned, social networks can have a strong impact on purchasing decisions during the purchase of hotel products or services (Pinto et al, 2015).

\section{Research}

The influence of Internet distribution systems and social networks on the promotion, sales, and quality of hotel services (with 4- and 5-star hotels in the city of Nis)

The main point of this research is to identify the usage and the impact of the Internet distribution systems and social networks on the promotion, sales, and quality of hotel services. To collect data, a non-standardized questionnaire containing close-ended questions was created. Thequestionnaire was given in eight hotels, categorized as4- and 5-starhotels in the city of Niš, as shown in chart no.1. The target group of respondents consisted of hotel managers. The questionnaire form contained 12 questions, related to the categorization of hotels, the way in which reservations of accommodation capacity is performed, target guests segments of the analyzed hotels, channels of sales in the hotel business, representation of forms of indirect sales in the hotel business, application of innovation in consumer awareness, cooperation with IDS, key benefits and shortcomings of cooperation with IDS for the hotels in question, the use and application of social media, the percentual contribution of sales through social networks. 
Chart no.1: an overview of analyzed hotels by categories

\begin{tabular}{|c|c|c|}
\hline Serial number & Hotel name & Hotel category \\
\hline 1 & Hotel Ambassador & $* * * *$ \\
\hline 2 & Garni Hotel Zen & $+* * *$ \\
\hline 3 & Art Loft Garni Hotel & $* * * *$ \\
\hline 4 & Hest Western Hotel My Place & $+* * *$ \\
\hline 5 & Hotel Ni\$kiCvet & $* * * *$ \\
\hline 6 & Hotel Tamy Residence & $* * * *$ \\
\hline 7 & Hotel Nais & $* * * *$ \\
\hline 8 & & \\
\hline
\end{tabular}

Chart 1, source: author

The previous chart number 1 shows hotels in Niš categorized as four-and five-star hotels in Niš.

To get acquainted with the needs of consumers and match the offer to the demand, which represents the key to a successful business, it is necessary to performnumerous analyses and do extensive research. The hotel identifies and determines the target group of consumers per research and analysis results. The following is a graphical representation onthe Likert's scale (from 1-irrelevant to 5- the most important) of target segments for guestsfrom the observed hotels.

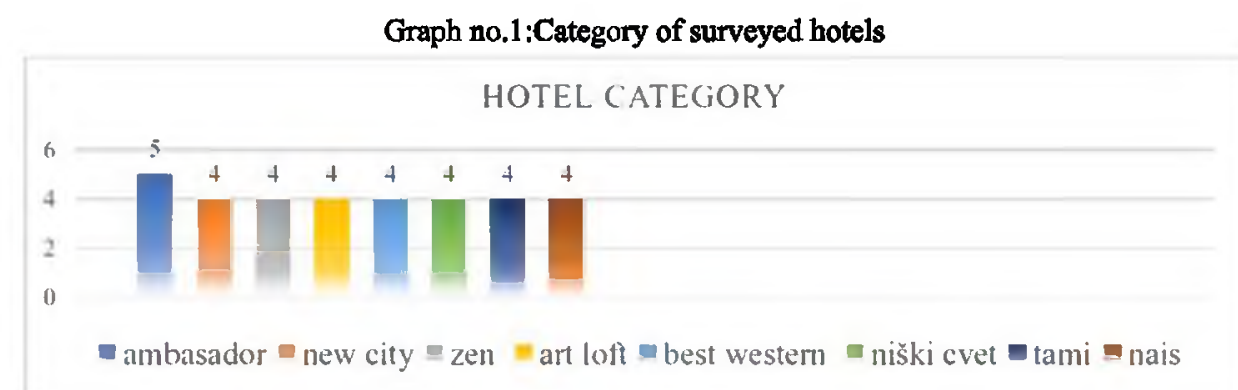

Graph no.1 shows hotels in Niצ categorized as four- and five-star hotels in Nis, source: author

The key to a successful business is getting to know the needs and desires of consumers, as well as matching supply to the demand requirements, but this requires the implementation of numerous researches and analyses. Thanks to the results of research and analyses, a hotel identifies and determines the target group of consumers. The following is a graphical representation on the Likert's scale (from 1-irrelevant to 5- the most important), showing target guest segments from the observed hotels. 


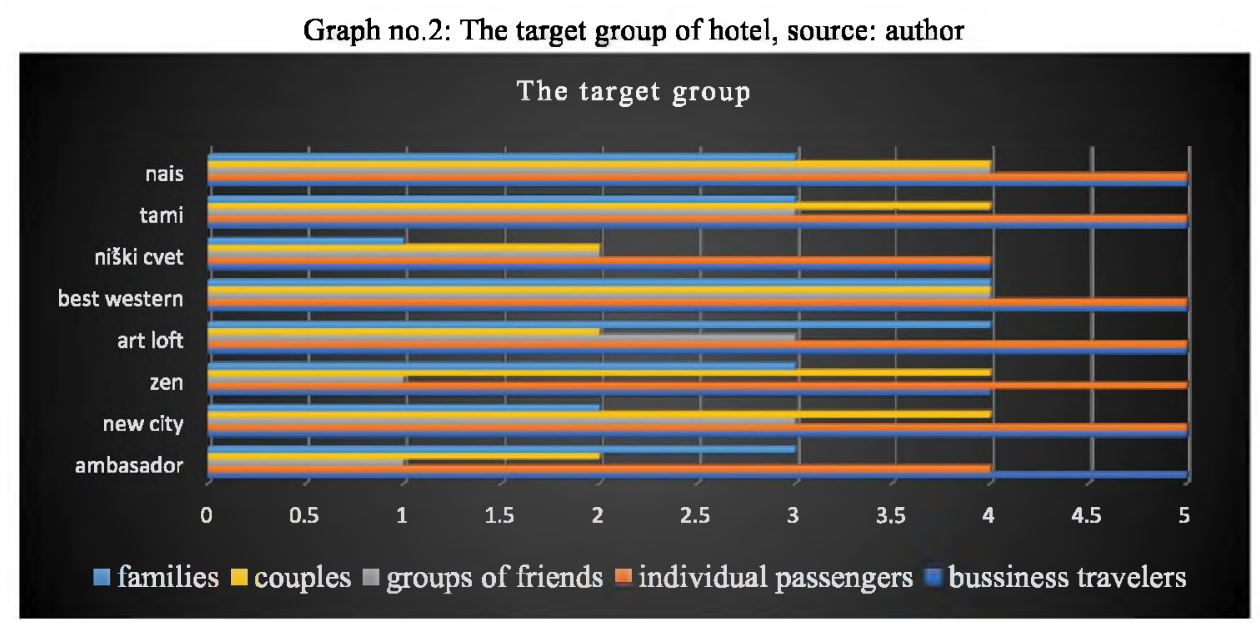

The data presented in graph no. 2 show that business travelers represent the most important market segment. This segment is the least price-sensitive and it does the best verbal promotion. Group of friends and individual passengers are just below business travelers and they are also important for hotels. Couples and families, inthe observed hotels, show the least important target segment of guests, and at the same time, they are the segment that visits observed hotels the least.

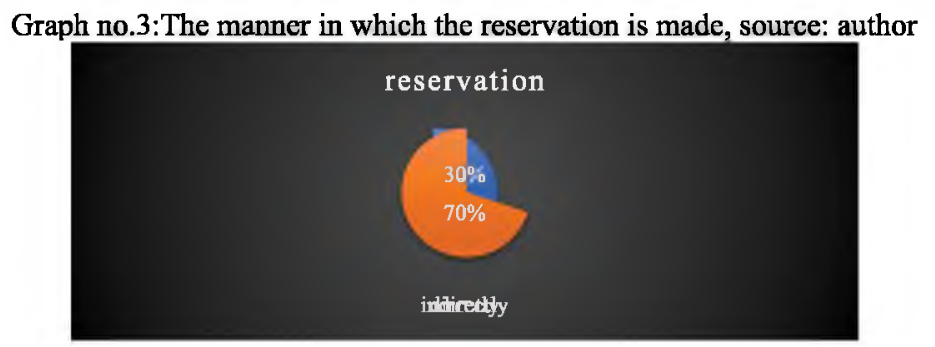

In graph no.3, the presented results of the research show that in the hotel business, the direct saleis more representedthanthe indirect sale. More than half of reservations, $70 \%$, are done directly. Reservation of hotel accommodation capacities indirectly can be done through GDS, IDS, tour operators, local travel agencies, and local and regional travel agencies. The next one is graph no.4, on which are shown forms of indirect sales in hotels. Observed hotels mostly cooperate in business management with Internet distribution systems, as well as with global distribution systems. Cooperation with IDS contributes to better market coverage for hotels, an increase in the number of reservations, image acquisition, as well a better awarenessof how they are positioned in the market. The greatest income for hotels is made from the total sales, through the cooperation with IDS. Also, the cooperation with IDS provides apossibility of facilitated business to the hotel, a larger number of realized reservations, thus better market coverage, too. High commissions on the IDS side, as well as ranking according to grades on portals, show a slight disadvantage of cooperation between IDS and hotels. 
Graph no.4: Representation of forms of indirect sales in the hotel, source: author

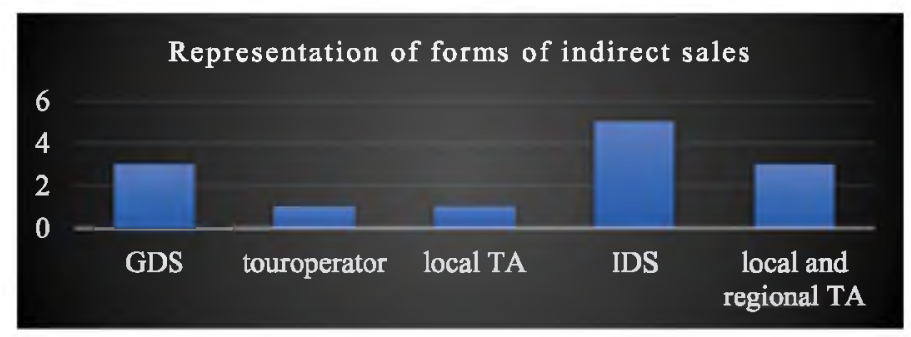

Graph no.5: IDS with which hotels cooperate the most, source: author

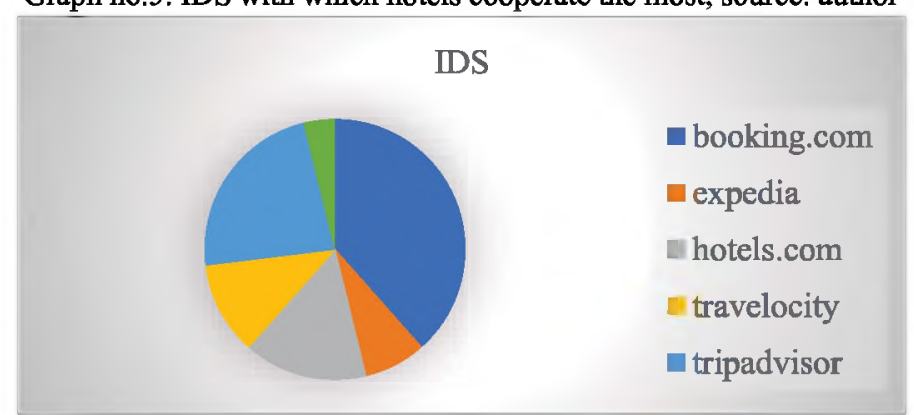

The data presented on graph no.5 shows that booking.com is the leading IDS, with whom hotels cooperate the most, that is, the IDS through which observed hotels make the largest number of reservations throughouta year.

Graph no.6: Key benefits of cooperation with IDS, source: author

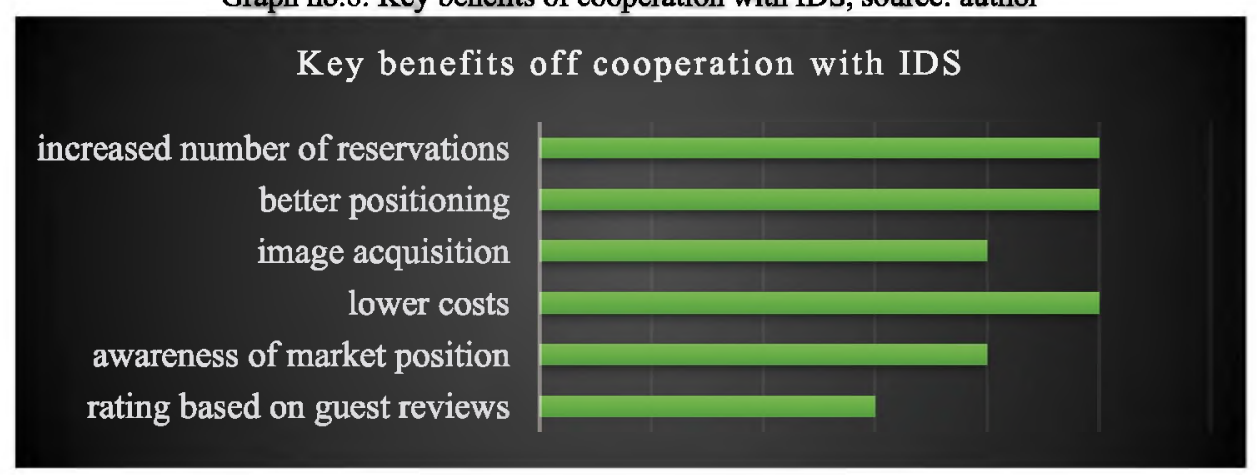

On graph no. 6 therearekey point indicatorson the advantages of cooperation with IDS. As the greatest advantages of cooperation with IDS, hoteliers state a larger number of reservations, lower costs, and better positioning on the market. Better coverage on the market is achieved through the cooperation with IDS, as well as an increase in reservations, and verbal or written promotion through comments by hotel guests. Good ratings on the portals, as well asverbal promotions byguests who stayed in the hotel, provide an opportunity of making new potential guests. IDSproves to bea perfect advertisement for development and growth in business. 
Usage, as well as the practical application of digital media in the hotel business, is very important. In graph no.7, the results of usage of social media in the business of the observed hotels are shown.

Graph no.7: Use of digital media in hotels, source: author

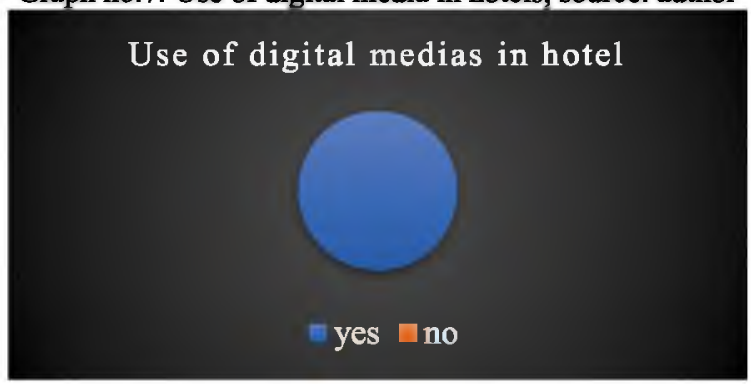

Social networks have a strong influence on consumers when shopping and at all stages of tripplanning. Social networks encourage tourists when choosing a trip, they can stimulate new ideas in the minds of consumers, introduce new destinations. The hotel business, to become a leader in the market, must be ahead of the competition. Promotion through social networks is the biggest advantage of using social networks in business management. Graph no.8 presents social networksused by hoteliers for promotion, sales, and service quality assessment (based on comments of guests). Facebook and Instagram represent leading social networks, networks that are of the greatest importance to the hotelsthat wish to increase profits. Social networks are also a way of free marketing for the hotel.

Graph no.8: Social networks, source: author

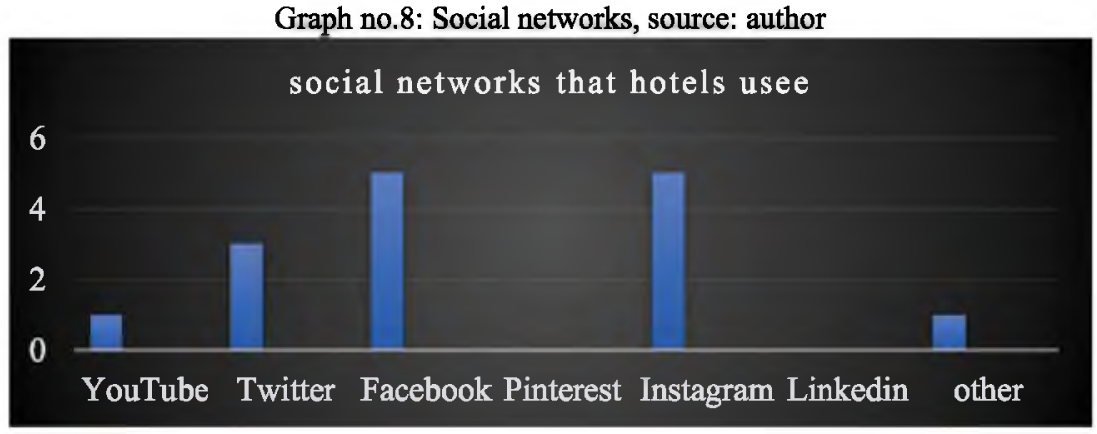

Graph no.9: Are social networks important in the promotion and sales of hotel products? source: author

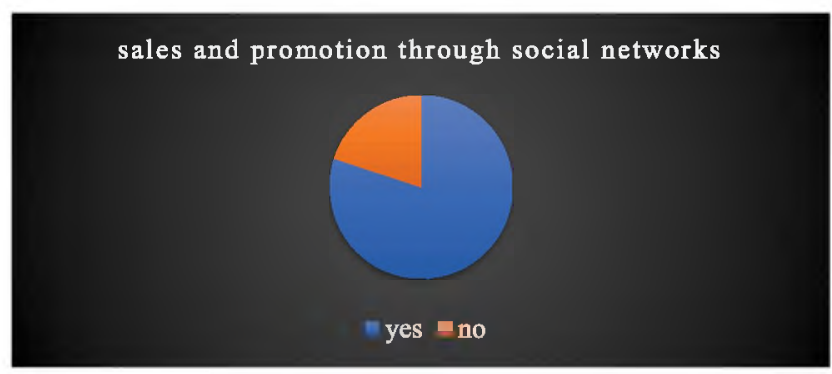


Social networks seem to bea very important way of promotion and sales of services for hotels, which is shown in graph no.9. Social networks make business easier - since the hotel products and services are intangible, through social networks potential guests can experience these services, either through various videos and pictures or via comments of guests, which are shown on the profile of the hotel. Thanks to the availability of information, pictures, and videos on social networks, profit from sales havethe potential to increase significantly.

\section{The conclusion}

A conclusion that can be drawn from the key points presented in this work is that the use of modern information technologies is an unavoidable componenton the path towards a better hotel business. Additionally, it is established that the application of IDS and social networks can positively influence consumers and the hotel's position inthe market. The main advantages of social networks are reduction of costs, speed of business, and marketing improvements. The business management of hotels must be based on innovations, primarily on acceptance and introduction of innovations in business, with the goal of improving the business and increasingthe number of incoming customers. The ultimate goal is creating higher profits and a more successful company through monitoring global trends. Based on the obtained research results, it can be concluded that the most represented segment of guests is the class of business travelers and that IDS is the most common form of indirect sales forthe analyzed hotels. The cooperation between a hotel and IDS, according to the analysis, contributes to the increase in the number of reservations, lower costs and better positioning on the market. The hotel business, to become a leader in the market, must be ahead of its competitors. Based on the results of research, the leading social networks which are used by hotels for promotion, sales, and service quality assessment are Facebook and Instagram.

\section{Literature:}

1. Andreson, C.K.(2011), Search, OTAs, and online booking: An expanded analysis of the billboard effect. Cornell Hospitality Report (11(8));

2. Baker M. at Hart S.(2008), The marketing book Routledge, Institute of Marketing London, UK;

1. B a r jaktarović D . ( $\begin{aligned} & 2 \\ & 0\end{aligned} 14$ ), Upravljenjekvalitetom $u$ hotelijerstvu, UniverzitetSingidunum, Beograd;

2. Buhalis D., at Law R.(2008), Progress in information technology and tourism management: 20 years on and 10 years after the Internet- The state of eTourism research. Tourism management (29);

3. Buhalis D. at Molinaroli E.(2003) Entrepreneurial networks in the Italian eTourism. Information Technology and Tourism, 5(3);

4. Cantallops A.S. at Salvi F.(2014) New consumer behavior: A review of research on eWOM and hotels. International Journal of Hospitality Management;

5. Clemons E.K. at Gao G.G.(2008) Consumer informedness and diverse consumer purchasing behaviors: Traditional mass-market, trading down, and trading out into the long tail. Electronic Commerce Research at Applications; 
6. Čačić K. at Mašić S.(2013) Uticaj portala TripAdvisor na poslovanje hotela u Srbiji. Marketing (44(3));

7. Comić Đ. at Kalmić L.(2011) Internet kao instrument globalnog monitornog kvaliteta u hotelijerstvu. Zbornik radova „Hotelska kuća", Beograd, HORES;

8. Del Chiappa G.(2013) Internet versus travel agencies- The perception of different groups of Italian online buyers. Journal of vacation Marketing;

9. Đorđević G.(2012) Unapređenje poslovne komunikacije primenom savremenih IT rešenja. EMC Review, časopis za ekonomiju(4);

10. El-Gohary H.(2012) Factors affecting E-marketing adoption and implementation in tourism firms: An empirical investigation of Egyptian small tourism organisations. Tourism Management (5(33));

11. European Commission (2013) Business Model Tourism Link. European Commission;

12. Eyefortravel (2012) Travel Consumer ReportAvailableat:http://www.evefor travel.com/sites/default/files/Extract Consumer Report United Kingdo m $201213 \quad 0.0 d f$.

13. GoogleT.I.(2013) The 2013 traveler. Availableat:http://www.google.ca/ think/research-studies/ 2013-traveler.html

14. Henning-Thurau T., Gwinner K.P., Walsh G. at Gremler D.D.(2004) Electronic WOM via consumeropinion platforms: what motivates consumers to atriculate themselves on the Internet? Journal of interactive marketing(18(1));
15. Holloway J.(2004) Marketing for Tourism. Essex: Pearson Education Limited;

16. $\mathrm{Hu}$ N., Bose I., Koh N.S. at Liu L.(2012) Manipulation of online review: An analysis of ratings, readability and sentiments. Decision Support Systems (52(3));

17. Jobber D., at Ellis-Chadwick F.(2012) Principles and practice of marketing (No.7th) McGraw-Hill Higher Education;

18. Kaplan A.M. at Haenlein M.(2011) The early bird catches the news: Nine things you should know about microblogging. Business Horizons (54(2));

19. Kauffman R.J. at ChircuA.M.(2000) Reintermediation strategies in bussiness-to-bussiness electronic commerce. International Journal of Electronic Commerce(4);

20. Kovačević M., Pavlović K. at S̆ $\mathrm{u}$ t i ć V. ( $\left.\begin{array}{llll}2 & 0 & 1 & 6\end{array}\right)$, Upotrebainformacionokomunikacionihtehnologija u RepubliciSrbiji, Republičkizavod za statistiku, Beograd(12(76));

21. Kotler P.(2006), Marketing for Hospitality and Tourism, Prentice Hall, New Jersey;

22. Kovačević M., Pavlović K. at S̆ u t i ć V. ( ( $\left.\begin{array}{llll}2 & 0 & 1 & 6\end{array}\right)$, Upotrebainformacionokomunikacionihtehnologija $u$ RepubliciSrbiji,Republičkizavod za statistiku, Beograd(12(76));

23. Kotler P.(2006), Marketing for Hospitality and Tourism, Prentice Hall, New Jersey; 
24. Kotler P., Browen J. et Makens J.(2010) Marketing u ugostiteljstvu, hotelijerstvu i turizmu.Zagred: MATE;

25. Law R.(2009) Disintermediation of hotel reservations: The perception of different groups of online buyers in Hong Kong. International Journal of Contemporary Hospitality Management(21);

26. Law $R$, at Cheung C.(2006) A study of the perceived importance of the over all website quality of different classes of hotels. International Journal of Hospitality Management(25(3));

27. Law R. at JogaratnamG.(2005)A study of hotel information technology applications. International Journal of Contemporary Hospitality Management(17(2));

28. LekhanyaM.L.(2014) The Impact of Viral Marketing on Corporate Brand Reputation, International Business at Economics Reseach Journal(13(2));

29. Lincoln S.R.(2009) Mastering Web 2.0: transform your business using key website and social media tools. London: Kogan Page Publishers;

30. Litvin S.W., at Hoffman L.M.(2012) Responses to consumer-generated media in the hospitality market placce an empirical study. Journal of Vacation Marketing(18(2));

31. Litvin S.W., Goldsmith R.E., at Pan B. (2008) Electronic WOM in hospitality and tourism management. Tourism management(29(3));

32. MinazziR.(2015) Social Media Marketing in Tourism and Hospitality. Spinger;

33. MinazziR.(2015) The Digitalization of WOM. Social Media Marketing in Tourism and Hospitality;
34. Mukherjee A., Lui B. et Giance N.(2012) Spotting fake reviewer g roups i n con sum er reviews.Proccedings of the 21 st international conference on World Wide Web ACM;

35. Nielsen(2012)State of themedia-The social media report2012. Nielsen http://www.nielsen.com/us/en/insig hts/reoorts/2012/state-of-the-socialmedia-redort-2012.html.

36. NjegušA.(2010) Informacioni sistemi u turizmu $i$ hotelijerstvu, Beograd, Univerzitet Singidunum;

37. O'Connor P.(2010) Managing a hotels image on TripAdvisor. Journal of Hospitality Marketing and Management(19(7));

38. O'Connor P. at Frew A.J.(2002) The future of hotel electronic channels of distribution. International Journal of Hospitality Management(23);

39. Papathanassis A.at Knolle F.(2011) Exploring the adoption and processing of online holiday review: A grounded theory approach. Tourism Management(32(2));

40. Ryan D. at Jones C.(2009) Undersanding Digital marketing strategies for engaging the digital generation;

41. Sorkup A. at Kostić M.(2009) IT kao generator inovacija u poslovnom sis te mu, Zbornik radova, majskakonferencija o strategijskom menadžmentu, Zaječar 2009;

42. Spasić V. at Pavlović D.(2013) Uloganovih elektronskih posrednika u prodaji kapaciteta u hotelskoj industriji. LX medunarodni naučnostručni simpozijum „, Hotelska kuća 2013", HORES, Zlatibor; 
43. Stanković- Kostić M., Štavljanin V. at Filipović V.(2013) Social media in Marketing and PR.JITA, Journal of Information Technology and Aplications(2(45));

44. ŠaracM.(2015) Internet marketing, Beograd, UniverzitetSingidunum;

45. Toh R.S, Raven P. at DeKay F.(2011) Selling Room: Hotels vs. Third-Party Websites. Cornell Hospitality Quartetly(52(2));

46. Xiang Z., Wang D., O'Leary J. at Fesenmaier D.(2014) Adapting to the internet: trends in travelers use of the web for trip planning. J Travel Res;

47. XieK.L.,Zhang Z. at Zhang Z.(2014) The business value of online consumer reviews and management response to hotel performance. International Journal of Hospitality Management(43);
48. Ye Q., Law R. at Gu B.(2009) The impact of online user reviews on hotel room sales. International Journal of Hospitality Management(28(1));

49. Ye Q., Law R., Gu B. at Chen W(2011) The influence of user-generated content on traveler behavior: An investigation on the effects of WOM to hotel online bookings. Computers in Human Behavior(27(2));

50. Živković R.(2011), Ponašanje potrošača, Beograd, Univerzitet Singidunum. 